\title{
Research on the Relationship between Students' Learning Adaptability and Learning Satisfaction under the Mobile Media Environment
}

\author{
https://doi.org/10.3991/ijet.v17i02.28549 \\ Guanghui Liu \\ School of Economics and Management, Jiaozuo University, Jiaozuo, China \\ liuguanghui@jzu.edu.cn
}

\begin{abstract}
The effective realization of the balance between the supply and demand of students' personalized learning and the shortage of offline classroom teaching resources is of great significance to large-scale online learning. Based on the relevant theories of learning adaptability, this paper analyzes the five dimensions of students' learning adaptability to learning satisfaction in the mobile social media environment and studies the mediating effect of mobile social media familiarity on students' learning adaptability and learning satisfaction. The results show that the Cronbach's $\alpha$ coefficient of the overall questionnaire is 0.930 and the KMO value is 0.873 , indicating that the research data have good reliability and validity. Learning motivation, teaching model, learning ability, learning attitude, and learning environment have a significant positive effect on learning satisfaction. The average learning satisfaction of students not familiar with the use of mobile social media $(3.70 \pm 0.55)$ is significantly lower than that of students familiar with using mobile social media $(4.00 \pm 0.46)$. The research results of this paper provide data support and strategic reference for how to effectively use the fragmented content of mobile social media and provide highquality online learning support services.
\end{abstract}

Keywords - mobile social media, students, learning adaptability, learning satisfaction, mesomeric effect

\section{$1 \quad$ Introduction}

At present, China is building a socialist modernization power in an all-around manner and has implemented measures to build a strong country through education. At the same time, the Chinese government at all levels has been attempting to accelerate the development of education informatization by covering all aspects of education informatization construction and application through education management informatization, campus informatization, informatization teaching practice, network learning space construction and application, and teaching informatization network security. Education has a strong development potential as an important application scenario of new infrastructure construction. With the changes in media technology and application environment, students' use frequency and dependence on social media 
have increased sharply. In the emerging media environment that can obtain massive information in real-time, it has become an inevitable trend for students to carry out online learning through mobile social media.

The mobile social platform has a large number of media learning resources, and the expression form is more scientific. In particular, the good system adaptability, feedback sense of operation, convenient communication, and other characteristics make the online learning environment more perfect. High and new technologies, such as multimedia technology, artificial intelligence, and network communication further promote mobile social media learning to become more acceptable. In the mobile social media environment, different teaching resources are transmitted to various learning groups, allowing it to adapt to the personalized needs and background characteristics of different learners, and realize the complete matching of teaching methods, teaching content presentation modes, and learners. Students' adaptive learning can make them better carry out mobile social learning. Different from the traditional faceto-face teaching method, the mobile social media learning method can make distance learning more efficient, convenient, and easy to operate, while meeting personalized learning needs. With the support of mobile social media, students can share their inherent knowledge system through rich and colorful social media, realize timely interaction with teachers and classmates, and gain the original motivation of knowledge construction. In the process of continuous learning, students can selfstudy, formulate personalized learning plans, adopt autonomous learning strategies, strengthen the control of the learning process and feedback of academic performance, and realize effective evaluation of self-study. The mobile social media learning platform analyzes the dynamic relationship between teachers' teaching behavior and learners' learning through massive amounts of big data, which is conducive to promoting students' sense of learning efficacy and ultimately improving students' learning satisfaction with mobile social media.

\section{Theoretical basis and hypothesis put forward}

\subsection{Theoretical basis}

Studies have shown that learning adaptability is an important part of students' psychological quality and the tendency of individual learners to overcome learning difficulties and achieve better learning performance. At present, scholars such as Löf (2010), Bell (2008), Porter (2010), and other scholars describe learning adaptation as an individual's efforts to make self-adjustment because of the objective environment and self-learning needs to achieve harmony [3] [4] [5]. Psychological and behavioral processes balance the environment. From the perspective of the more widely accepted definition of learning adaptability around the world, it includes two contents. One is that learners individually solve learning difficulties and obtain a balance of learning, which is referred to as better learning effect. According to the external learning conditions brought by new technologies, such as artificial intelligence and social media and the needs of their knowledge learning, learners can coordinate their psychological and 
behavioral learning states with the learning environment through self-regulation to achieve better learning effects. Students are the subjects of adaptation and new technologies, such as artificial intelligence and social media, are the objects of adaptation as the environment or means to support learning activities, and knowledge learning is the task or goal of learning. Students' learning adaptability includes psychological, physiological, and behavioral adaptability.

\subsection{Hypothesis proposal}

Many studies have shown that the dimensions of learning adaptability are complex. This paper uses five commonly used aspects to measure learning adaptability: learning motivation, teaching mode, learning ability, learning attitude, and learning environment. Regarding the relationship between learning motivation and learning satisfaction, Schiefele believed that learning motivation is composed of learners' intrinsic emotional correlation and value correlation [6]. Oxford believed that learning motivation is the original driving force to improve the effect of language learning [7]. Lin showed that digital learning has a better positive effect on learning motivation than traditional teaching [8]. Harandi took the survey object of Al Zaha University in Tehran as an example and showed the existence of a close relationship between online learning methods and student motivation [9].

The results of Krapp show that learning motivation is the preferred influencing factor of learning [10]. Puspitarini reported that using technology as a medium in the learning process can improve students' learning motivation [11]. Csizér believed that language learning motivation is a complex composite structure. Research has shown that strengthening the integration of language learning can improve the overall satisfaction of language learning [12]. Su reported that integrating mobile and game technology into the plant learning process can obtain better academic achievement and higher motivation, revealing the positive relationship between academic achievement and motivation [13]. Tuckman has shown that learning motivation can promote students to strengthen their learning skills and cultivate their high-level thinking and independent learning [14]. Therefore, hypothesis is proposed in this paper.

H1: Learning motivation can significantly and positively promote learning satisfaction.

Concerning the relationship between teaching mode and learning satisfaction, Alsowat showed that the overall learning satisfaction of students is at a high level under the latest teaching mode of flip class [15]. Cheok found that user-related characteristics, organization-related characteristics [16], and e-learning system characteristics are the main factors that affect middle school teachers' e-learning satisfaction. Bini has shown that scientific and reasonable teaching modes can significantly improve teachers' teaching efficiency [17]. Lee reported that teachers' innovation in teaching mode has a significant positive effect on students' learning satisfaction [18]. Guolla believed that teachers' higher level of teaching quality is related directly to students' course satisfaction [19]. Cleak reported that teaching supervision of teachers have a high degree of satisfaction with students' social practice [20]. Joo conducted a questionnaire survey with students of online learning at a university in South Korea and 
found that teachers' good teaching presence is a significant predictor of learner satisfaction [21]. Calvo showed that length of study and class size are significantly related to student satisfaction [22]. Mohammed, G. S believed that micro-learning provided a new teaching mode that can divide knowledge and information into small pieces and pass them to learners [23]. The use of micro-learning technology can improve the effectiveness and efficiency of learning. Therefore, this paper proposes the following hypothesis:

$\mathrm{H} 2$ : Teaching mode can positively promote learning satisfaction.

On how learning ability affects learning satisfaction and learning performance, Seo, showed the existence of a significant correlation between self-learning ability and learning satisfaction under the mixed learning mode [24]. Kim found that various extracurricular activities can stimulate students' interest in their major [25]. Choi reported that students with stronger learning abilities are more satisfied with their internship [26]. Hoskins showed that students with strong learning abilities also performed better in online tests [27]. Babini pointed out that a virtual reality environment played a greater role in improving students' learning ability [28]. Cheng showed that high-order cognitive learning skills are positively correlated with participants' performance [29]. Siriwongs found that through self-directed learning, personal learning skills can be improved [30], which is conducive to enriching students' life experiences. Shinkareva indicated that students with a higher level of self-directed learning ability may show a higher level of learning and self-efficacy. Therefore, this article proposes the following hypothesis [31]:

H3: Learning ability can positively promote learning satisfaction.

On how learning attitude affects learning satisfaction, Vaughan showed that a positive learning attitude can promote positive achievements [32]. Mahmoudi, reported that computer-assisted English learning can significantly improve students' positive attitude towards learning [33], and their attitude is positively correlated with their academic performance. Akinbobola analyzed the attitude of Nigerian senior high school students to learn physics and found that students' active learning attitude was the key to achieving excellent results [34]. Bhaskar reported that students' attitudes towards English learning affected their English performance [35]. Nugraha indicated that a close relationship could be observed between the scientific attitudes and learning style preferences of junior high school students in Bandung [36], Indonesia. Farooq believed that e-learning plays an effective role in the field of education [37]. Students' good learning attitude can make them accept online learning more quickly. Ajewole reported that scientific learning using discovery methods may enable learners to show more positive attitudes towards problem identification and problemsolving than learning using interpretive methods [38]. Therefore, this paper proposes the following hypothesis:

H4: Learning attitude can positively promote learning satisfaction.

How the learning environment affects learning satisfaction. The mobile social media learning environment includes hardware facilities and software resources for online learning. Van der Kleij found that the more perfect the instant feedback interaction in the computer environment [39], the more obvious the learning results. Frenzel found that students' overall environmental perception of the class is closely relat- 
ed to students' mathematics mood and academic performance [40]. Tarr found that standard learning environment regulated the influence of course types on students' academic performance [41]. Harrati showed that the good usability of the online learning system will significantly improve the real acceptance and satisfaction of students using the E-learning system [42]. Violante reported that in a web-based learning environment, the visual and interactive functions embedded in applications will increase the positive satisfaction of doctors and biomedical engineering students in using medical equipment [43]. Pham showed that overall E-learning service quality is positively correlated with E-learning student satisfaction [44]. Yilmaz reported that in the flipped classroom teaching model, students' e-learning readiness is an important factor influencing their satisfaction and motivation. Therefore, this paper puts forward the following hypothesis [45]:

H5: A learning environment can significantly positively promote learning satisfaction.

Regarding the proficient use of mobile social media, the research results of Wong, (2020), Lewis (2010), and Gikas (2013) show that learners' proficient use of mobile social media can effectively promote their learning effects [46] [47] [48], improve the level of learning performance, and achieve cross-temporal learning in a shorter period, without the phenomenon of relaxing learning due to unfamiliar online learning platforms. Therefore, this paper proposes the following hypothesis:

H6: Familiarity with using mobile social media plays an intermediary role in learning adaptability positively promoting learning satisfaction.

\section{$3 \quad$ Research and design}

\subsection{Questionnaire design}

Based on the existing research literature, we compiled the "Learning Adaptability and Learning Satisfaction of Students in the Mobile Social Media Environment," which includes three aspects and a total of 40 topics. The first aspect is the basic information of the respondents, and include four topics: gender, grade, major, and familiarity with mobile social media for learning. The second part is the core variables. This article first studies and draws on the "University Students" Learning Adaptability Scale" compiled by Feng Tingyong [1], which is widely used in China, and combines the characteristics of students' online learning situations using mobile social media. The online learning adaptability questionnaire is developed from five dimensions, namely learning motivation, teaching mode, learning ability, learning attitude, and learning environment. There are 3, 3, 8, 4, and 5 questions, or a total of 23 questions. The questionnaire uses Likert's five-point scoring method. The higher the score, the better the adaptability of students in the online learning environment. Then, the learning satisfaction questionnaire is based on the learning satisfaction questionnaire of Topala [2]. We selected eight questions to finally measure learning satisfaction. On the use of mobile social media, the research team developed five topics on its own. 


\subsection{Research objects}

The official survey scope of this research is undergraduates from the School of Economics and Management of a general provincial university in Hunan Province. At present, Hunan Province has fully implemented the "Hunan Province Internet + Education Action Plan (2019-2022)", which is a pilot university of the "Hunan Province Education Informatization Innovation Pilot Project in 2020". At present, to comprehensively promote the construction of education informatization 2.0 pilot province, the university has built a mobile social learning platform on campus, which has a relatively good mobile learning environment. At the same time, to ensure the filling quality and recovery rate of the questionnaire, three graduate students from the author's research group went to the School of economics and management of the university to conduct a face-to-face paper questionnaire survey on students in their spare time in class. A total of 217 questionnaires were distributed and 206 were recovered. After excluding the invalid questionnaires, 195 final questionnaires were obtained, with an effective recovery rate of $94.66 \%$. The questionnaire results were edited by the research group with SPSS22.0 software. The details of the respondents are shown in Table 1.

Table 1. Descriptive statistics results

\begin{tabular}{|l|c|c|c|c|}
\hline Name & Option & Frequency & percentage(\%) & Cumulative percentage(\%) \\
\hline \multirow{3}{*}{ Gender } & Male & 70 & 35.9 & 35.9 \\
\cline { 2 - 5 } & Female & 125 & 64.1 & 100 \\
\hline \multirow{4}{*}{ Grade } & Freshman & 24 & 12.31 & 12.31 \\
\cline { 2 - 5 } & Sophomore & 70 & 35.9 & 48.21 \\
\cline { 2 - 5 } & Junior & 74 & 37.95 & 86.15 \\
\cline { 2 - 5 } & Senior & 27 & 13.85 & 100 \\
\cline { 2 - 5 } & Statistics & 28 & 14.36 & 14.36 \\
\cline { 2 - 5 } & Finance & 32 & 16.41 & 30.77 \\
\cline { 2 - 5 } & Marketing management & 27 & 13.85 & 44.62 \\
\cline { 2 - 5 } & $\begin{array}{c}\text { Human resource manage- } \\
\text { ment }\end{array}$ & 27 & 13.85 & 58.46 \\
\cline { 2 - 5 } & $\begin{array}{c}\text { International economy and } \\
\text { trade }\end{array}$ & 29 & 14.87 & 73.33 \\
\cline { 2 - 5 } & Accountancy & 52 & 26.67 & 100 \\
\cline { 2 - 5 } & No & 88 & 45.13 & 45.13 \\
\hline $\begin{array}{l}\text { Are you } \\
\text { familiar with } \\
\text { mobile social } \\
\text { media for } \\
\text { learning }\end{array}$ & Yes & 107 & 54.87 & 100 \\
\hline Total & & 195 & 100 & 100 \\
\hline
\end{tabular}

Table 1, that the vast majority of students in this school of economics and management were female, which is also in line with the current situation that most universities in China have female students majoring in economics and management. The number of senior students participating in the questionnaire is small because of their 
internship. Due to the good employment of accounting majors, the school of economics and management recruits about four classes a year, twice as many as other majors. Therefore, more students majoring in accounting participated in answering the questionnaire. The overall distribution of respondents in Table 1 is scientific and reasonable, which lays a good foundation for the questionnaire analysis of this paper.

\section{$4 \quad$ Result analysis}

\subsection{Reliability and validity analysis}

This article uses the reliability analysis function of SPSS software (version number 22.0) to test the reliability of the questionnaire designed in this article. The results are shown in Table 2 . The results show that the reliability values of all dimensions of the questionnaire are greater than the standard value of 0.782 , and the reliability coefficient of the whole questionnaire is 0.930 , which is greater than 0.9 , thereby indicating that the reliability quality of the research data is very high. Therefore, the research questionnaire designed in this paper has high reliability and good internal consistency.

Table 2. Reliability test results

\begin{tabular}{|c|c|c|c|c|c|}
\hline $\begin{array}{c}\text { Variable } \\
\text { name }\end{array}$ & Problem item & $\begin{array}{c}\text { Total correlation of } \\
\text { correction terms(CITC) }\end{array}$ & $\begin{array}{c}\text { Item deleted } \alpha \\
\text { coefficient }\end{array}$ & $\begin{array}{c}\text { Cronbach } \alpha \\
\text { coefficient }\end{array}$ & $\begin{array}{c}\text { Cronbach } \alpha \\
\text { coefficient }\end{array}$ \\
\hline \multirow{3}{*}{$\begin{array}{l}\text { Learning } \\
\text { motivation } \\
\text { (factor1) }\end{array}$} & A1 & 0.714 & 0.771 & \multirow{3}{*}{0.841} & \multirow{22}{*}{0.930} \\
\hline & A2 & 0.703 & 0.782 & & \\
\hline & A3 & 0.699 & 0.786 & & \\
\hline \multirow{3}{*}{$\begin{array}{l}\text { Teaching } \\
\text { model } \\
\text { (factor2) }\end{array}$} & B1 & 0.615 & 0.795 & \multirow{3}{*}{0.814} & \\
\hline & B2 & 0.725 & 0.68 & & \\
\hline & B3 & 0.66 & 0.751 & & \\
\hline \multirow{8}{*}{$\begin{array}{l}\text { Learning } \\
\text { ability } \\
\text { (factor3) }\end{array}$} & $\mathrm{C} 1$ & 0.654 & 0.838 & \multirow{8}{*}{0.859} & \\
\hline & $\mathrm{C} 2$ & 0.555 & 0.848 & & \\
\hline & C3 & 0.588 & 0.844 & & \\
\hline & $\mathrm{C} 4$ & 0.577 & 0.845 & & \\
\hline & $\mathrm{C} 5$ & 0.64 & 0.839 & & \\
\hline & C6 & 0.535 & 0.854 & & \\
\hline & $\mathrm{C} 7$ & 0.754 & 0.823 & & \\
\hline & $\mathrm{C} 8$ & 0.577 & 0.845 & & \\
\hline \multirow{4}{*}{$\begin{array}{l}\text { Learning } \\
\text { attitude } \\
\text { (factor4) }\end{array}$} & D1 & 0.715 & 0.91 & \multirow{4}{*}{0.910} & \\
\hline & D2 & 0.843 & 0.866 & & \\
\hline & D3 & 0.843 & 0.866 & & \\
\hline & D4 & 0.783 & 0.887 & & \\
\hline \multirow{4}{*}{$\begin{array}{l}\text { Learning } \\
\text { environ- } \\
\text { ment(factor5) }\end{array}$} & E1 & 0.575 & 0.858 & \multirow{4}{*}{0.859} & \\
\hline & E2 & 0.695 & 0.824 & & \\
\hline & E3 & 0.684 & 0.83 & & \\
\hline & E4 & 0.7 & 0.822 & & \\
\hline
\end{tabular}




\begin{tabular}{|c|c|c|c|c|}
\hline & E5 & 0.745 & 0.811 & \\
\hline \multirow{8}{*}{$\begin{array}{l}\text { Learning } \\
\text { adaptabil- } \\
\text { ity(factor6) }\end{array}$} & $\mathrm{Y} 1$ & 0.529 & 0.751 & \multirow{8}{*}{0.782} \\
\hline & $\mathrm{Y} 2$ & 0.502 & 0.756 & \\
\hline & $\mathrm{Y} 3$ & 0.615 & 0.737 & \\
\hline & Y4 & 0.668 & 0.724 & \\
\hline & Y5 & 0.304 & 0.795 & \\
\hline & Y6 & 0.361 & 0.777 & \\
\hline & Y7 & 0.455 & 0.763 & \\
\hline & Y8 & 0.495 & 0.758 & \\
\hline \multirow{5}{*}{$\begin{array}{l}\text { Familiarity } \\
\text { with mobile } \\
\text { social media } \\
\text { (factor7) }\end{array}$} & M1 & 0.752 & 0.856 & \multirow{5}{*}{0.887} \\
\hline & M2 & 0.701 & 0.868 & \\
\hline & M3 & 0.711 & 0.866 & \\
\hline & M4 & 0.748 & 0.857 & \\
\hline & M5 & 0.718 & 0.864 & \\
\hline
\end{tabular}

The validity of the questionnaire structure is tested by performing the KMO and Bartlett's sphericity tests on the questionnaire before performing factor analysis on the questionnaire as shown in Table 3.

Table 3. KMO and Bartlett's test

\begin{tabular}{|l|c|c|}
\hline \multicolumn{2}{|l|}{ KMO value } & 0.873 \\
\hline \multirow{3}{*}{ Bartlett's sphericity test } & Approximate chi-square & 4235.82 \\
\cline { 2 - 3 } & $\mathrm{df}$ & 630 \\
\cline { 2 - 3 } & $\mathrm{p}$ value & 0 \\
\hline
\end{tabular}

The results in Table 3 show that the KMO and Bartlett tests are used to verify the validity. The table further shows that he KMO value is 0.873 , which is greater than 0.8 , and the research data are very suitable for extracting information. The corresponding P-value is 0.000 , which is less than the 0.05 significance level. Hence, the questionnaire on students' learning adaptability under the mobile social media environment is very suitable for exploratory factor analysis.

Table 4 shows that the diagonal line is the square root value of AVE, and the rest are the correlation coefficients. For Factors 1 to 5, the AVE square root value is greater than the maximum value of the absolute value of the correlation coefficient between factors, which means that the learning adaptability questionnaire has good discrimination validity.

Table 4. Discrimination validity: Pearson correlation and square root value of AVE

\begin{tabular}{|l|c|c|c|c|c|}
\hline & Factor1 & Factor2 & Factor3 & Factor4 & Factor5 \\
\hline Factor1 & 0.795 & - & - & - & - \\
\hline Factor2 & 0.667 & 0.776 & - & - & - \\
\hline Factor3 & 0.539 & 0.543 & 0.662 & - & - \\
\hline Factor4 & 0.481 & 0.538 & 0.59 & 0.852 & - \\
\hline Factor5 & 0.288 & 0.44 & 0.409 & 0.372 & 0.744 \\
\hline
\end{tabular}




\subsection{Regression analysis}

Table 5 shows the following:

1. Suppose H1 holds; that is, strong learning motivation can significantly and positively promote learning satisfaction. In China, students, as the main group of higher education, have experienced the college entrance examination system, and they have developed good study habits in high school and have sufficient learning motivation. At the same time, the lowest college entrance examination scores of students majoring in the school of economics and management in the universities investigated in this paper are high, about 40 points higher than the undergraduate admission line of China's college entrance examination. The individual learning motivation of these respondents is very obvious, and the original motivation for mobile social media learning is strong. The regression results shows that students with stronger learning motivation will take the initiative in viewing the learning process as a process of great significance and value. The learning process can meet their desire for knowledge, show their self-worth, and experience stronger learning satisfaction in the learning process.

2. Suppose H2 holds; that is, a good teaching model can significantly promote learning satisfaction. At present, China's universities at all levels should fully stimulate students' learning motivation. In particular, the universities surveyed in this paper attach importance to online teaching management and have issued online learning management measures that require teachers to supervise the whole process of students' online learning process and form a situation of teacher-student interaction in this process. At the same time, a good mobile social media environment enables teachers to make full use of the online platform, ensuring the length of interaction with students. Students also interact with teachers and classmates, thereby broadening their horizons and gaining new ideas and skills for learning. Benign teaching interaction can fully stimulate students' learning enthusiasm, especially the teachers in the surveyed colleges because they are doctors with good information-based teaching technology. Teachers innovate boldly in terms of teaching design, teaching process control, and teaching mode by reforming their online teaching mode and adopting international educational concepts, such as OBE, which effectively improves the learning satisfaction of students.

3. Suppose H3 holds. Learning ability can significantly and positively promote learning satisfaction. A large number of studies have shown that students' learning ability has a significant effect on their learning satisfaction in classroom learning. The biggest advantage of the learning platform in the mobile social media environment is that it has a huge amount of learning resources. The high abundance of learning resources makes it easy for students to be embedded in selective difficulties. They need to have a strong self-learning ability and choose key knowledge to make breakthroughs while studying comprehensively. Students continue to improve the adjustment level of self-learning and maintain a high learning ability by maintaining a high level of autonomous learning ability in senior high school and strengthening the sense of self-efficacy. Students with strong autonomous learning abilities can self-manage their learning process, bear the main responsibility of learning, 
stimulate the benign construction process of their learning knowledge, promote the awareness of intellectual activities, show their high-level thinking mode, and maintain their learning satisfaction at a high level.

4. Suppose H4 holds. Learning attitude can significantly and positively promote learning satisfaction. Students' good and positive learning attitude can make them pay more attention to learning, which in turn will affect the progress of learning and learning evaluation. Students with a more positive learning attitude can stimulate their endogenous learning motivation in the face of online learning difficulties, dare to challenge the difficulties in learning, and have stronger faith and will to overcome the difficulties. Therefore, students with a correct learning attitude can better complete the learning tasks, maintain a higher learning enthusiasm and patience, so that their learning satisfaction can reach and maintain a higher level.

5. Assume that H5 holds. The learning environment can positively promote learning satisfaction. Various learning environments of mobile social media are relatively mature, and a good hardware environment and software application environment of mobile social media ensure the improvement of students' learning satisfaction. At present, various mobile social media platforms make use of the latest artificial intelligence, big data, and other technologies to analyze the mobile social activities of students and give effective feedback to their learning results, and thus, students can quickly understand their learning results, adjust their learning status in time, cultivate good online learning habits, strengthen their willingness to learn online, promote students to adopt learning strategies that are more suitable for the mobile social media environment, meet their learning needs, and ensure that their learning satisfaction is at a high level.

Table 5. Regression results

\begin{tabular}{|l|c|c|c|}
\hline & Regression coefficients & 95\% CI & VIF \\
\hline Constant & $1.400^{* *}(9.503)$ & $1.111 \sim 1.689$ & - \\
\hline Factor1 & $0.103^{*}(2.577)$ & $0.025 \sim 0.182$ & 1.804 \\
\hline Factor2 & $0.179^{* *}(4.087)$ & $0.093 \sim 0.265$ & 1.811 \\
\hline Factor3 & $0.246^{* *}(6.296)$ & $0.169 \sim 0.322$ & 1.850 \\
\hline Factor4 & $0.084^{*}(2.506)$ & $0.018 \sim 0.149$ & 1.839 \\
\hline Factor5 & $0.056^{*}(2.008)$ & $0.001 \sim 0.110$ & 1.157 \\
\hline Sample size & \multicolumn{3}{|c|}{0.65} \\
\hline $\mathrm{R}^{2}$ & $\mathrm{~F}(5,189)=65.066, \mathrm{p}=0.000$ \\
\hline Adjust $\mathrm{R}^{2}$ & \multicolumn{3}{|c|}{0.623} \\
\hline F value & \multicolumn{3}{|c|}{} \\
\hline
\end{tabular}

$\mathrm{D}-\mathrm{W}$ value: 2.007

${ }^{*} \mathrm{p}<0.05{ }^{* *} \mathrm{p}<0.01$, the $\mathrm{t}$ value is in the parentheses

\subsection{Mediating effect analysis}

The results in Table 6 support hypothesis H6. Familiarity with the use of mobile social media plays a partial mediating effect in the positive promotion of students' 
learning adaptability and learning satisfaction. The main reason is that students have relatively strong learning abilities, can quickly adapt to the new mobile social media learning environment, and can become familiar with the operation of mobile social media within a short time. It also inspires universities to pay full attention to the construction of mobile social media software and hardware while constructing excellent mobile online learning resources, especially the interactive friendliness of mobile social media platforms. If students can accept and become familiar with mobile social media learning methods within a short time, they can improve their learning adaptability, become more accustomed to mobile social media learning methods, and comprehensively improve their learning satisfaction.

Table 6. Mediating effect model

\begin{tabular}{|l|c|c|c|c|c|c|c|c|c|c|}
\hline \multicolumn{1}{|c|}{ Item } & To & $\mathbf{A}$ & $\mathbf{B}$ & $\mathbf{a}^{*} \mathbf{b}$ & $\mathbf{a}^{*} \mathbf{b}$ & $\mathbf{a}^{*}$ & $\mathbf{a}^{*}$ & $\mathbf{a}^{*} \mathbf{b}$ & $\mathbf{c}^{\prime}$ & Partial \\
\hline tal c effect & & $\begin{array}{c}\text { Mediating } \\
\text { effect } \\
\text { value }\end{array}$ & $\begin{array}{c}\text { (Boot } \\
\text { SE) }\end{array}$ & $\begin{array}{c}\text { b (z } \\
\text { value) }\end{array}$ & $\begin{array}{c}\text { b (p } \\
\text { val- } \\
\text { ue) }\end{array}$ & $\begin{array}{c}\text { intermedi- } \\
\text { BootCI) } \\
\text { ary of } \\
\text { inspection } \\
\text { conclu- } \\
\text { sions }\end{array}$ \\
\hline $\begin{array}{l}\text { Learning adapt- } \\
\text { ability = } \\
\text { familiarity with } \\
\text { mobile social } \\
\text { media = } \\
\text { learning satis- } \\
\text { faction }\end{array}$ \\
$\begin{array}{l}* \\
\text { effect }\end{array}$
\end{tabular}

\subsection{T-test}

We use the T-test to determine whether familiarity with the use of mobile social media has a difference in learning satisfaction. Table 7 shows that familiarity with the use of mobile social media shows a significant level of 0.01 for learning satisfaction $(\mathrm{t}$ $=-4.117, p=0.000)$. The average learning satisfaction of students not familiar with the use of mobile social media (3.70) will be significantly lower than the average learning satisfaction (4.00) of students familiar with the use of mobile social media. It fully shows that under the impetus of China's educational informatization for many years, the students in contemporary universities have a high literacy of teaching informatization on the whole, especially in online learning. Mastering the use of methods and skills of mobile social media can make it more convenient and quicker to conduct mobile learning and promote learning satisfaction. However, students unfamiliar with mobile social media technology often have unfamiliar platform use or cumbersome operation experience, leading them to reject technology, thereby greatly reducing their learning satisfaction. No significant difference in learning satisfaction between different gender samples $(\mathrm{P}>0.05)$ was observed, which fully shows that the university has shown a good development trend in education information teaching, and that boys and girls can carry out mobile learning well. 
Paper — Research on the Relationship between Students' Learning Adaptability and Learning...

Table 7. T value test

\begin{tabular}{|c|c|c|c|c|}
\hline \multirow{4}{*}{ Learning satisfaction } & \multicolumn{2}{|c|}{ Familiar with mobile social media use (mean \pm SD) } & t & p \\
\cline { 2 - 5 } & $0.0(\mathrm{n}=88)$ & $1.0(\mathrm{n}=107)$ & & \\
\cline { 2 - 5 } & $3.70 \pm 0.55$ & $4.00 \pm 0.46$ & -4.117 & $0.000^{* *}$ \\
\cline { 2 - 5 } & \multicolumn{2}{|c|}{ Gender (mean \pm SD) } & \multirow{2}{*}{$\mathrm{p}$} \\
\cline { 2 - 5 } & $1.0(\mathrm{n}=70)$ & $2.0(\mathrm{n}=125)$ & & 0.278 \\
\hline
\end{tabular}

\section{Conclusions}

In the era of mobile Internet, the rapid popularization and application of social media have injected new elements into the online education and teaching mode of students. Mobile social media can effectively meet the teaching requirements of students, which are across time and space, fragmented and personalized. Based on the related theories of learning adaptability, this paper analyzes the five dimensions of students' learning adaptability under the mobile social media environment on learning satisfaction and studies the mediating effect of mobile social media usage familiarity on students' learning adaptability on learning satisfaction. The research results indicate that the Cronbach's $\alpha$ coefficient of this paper is 0.930 and the KMO value is 0.873 , indicating good reliability and validity. Five aspects of learning motivation, including teaching mode, learning ability, learning attitude, and learning environment can significantly and positively promote learning satisfaction. Familiarity with the use of mobile social media plays a part of the mediating effect in learning adaptability and positively promotes learning satisfaction. The average learning satisfaction of students familiar with the use of mobile social media (4.00) is higher than that of students who are not familiar with the use of mobile social media (3.70). In the future, we can continue to conduct in-depth research on the change of mobile learning mode supported by technology, the analysis of personalized learning needs of open education learners, and the innovative effects of social media on the management mode of traditional teaching mode.

\section{$6 \quad$ References}

[1] Tingyong, F., Ti, S., Xingwang, H., \& Hong, L. The Development of a Test about Learning Adjustment of Undergraduates. Acta Psychologica Sinica, 2006, vol. 38(05), pp. 762769.

[2] Topala, I., Tomozii, S. Learning satisfaction: validity and reliability testing for students' learning satisfaction questionnaire (SLSQ). Procedia-Social and Behavioral Sciences, 2014, vol. 128, pp. 380-386. https://doi.org/10.1016/j.sbspro.2014.03.175

[3] Löf, A. Exploring adaptability through learning layers and learning loops. Environmental Education Research, 2010, vol. 16(5-6), pp. 529-543. https://doi.org/10.1080/13504622. $\underline{2010.505429}$ 
Paper — Research on the Relationship between Students' Learning Adaptability and Learning...

[4] Bell, B.S., Kozlowski, S.W. Active learning: effects of core training design elements on self-regulatory processes, learning, and adaptability. Journal of Applied psychology, 2008, vol. 93(2), pp. 296. https://doi.org/10.1037/0021-9010.93.2.296

[5] Porter, C.O., Webb, J.W., Gogus, C.I. When goal orientations collide: effects of learning and performance orientation on team adaptability in response to workload imbalance. Journal of Applied Psychology, 2010, vol. 95(5), pp. 935. https://doi.org/10.1037/ $\underline{\mathrm{a} 0019637}$

[6] Schiefele, U. Interest, learning, and motivation. Educational psychologist, 1991, vol. 26(34), pp. 299-323. https://doi.org/10.1080/00461520.1991.9653136

[7] Oxford, R., Shearin, J. Language learning motivation: Expanding the theoretical framework. The modern language journal, 1994, vol. 78(1), pp. 12-28. https://doi.org/ $\underline{10.1111 / j .1540-4781.1994 . t b 02011 . x}$

[8] Lin, M.H., Chen, H.G. A study of the effects of digital learning on learning motivation and learning outcome. Eurasia Journal of Mathematics, Science and Technology Education, 2017, vol. 13(7), pp. 3553-3564.

[9] Harandi, S.R. Effects of e-learning on Students' Motivation. Procedia-Social and Behavioral Sciences, 2015, vol. 181, pp. 423-430. https://doi.org/10.1016/j.sbspro.2015.04.905

[10] Krapp, A. Interest, motivation and learning: An educational-psychological perspective. European journal of psychology of education, 1999, vol. 14(1), pp. 23-40.

[11] Puspitarini, Y.D., Hanif, M. Using Learning Media to Increase Learning Motivation in Elementary School. Anatolian Journal of Education, 2019, vol. 4(2), pp. 53-60.

[12] Csizér, K., Dörnyei, Z. The internal structure of language learning motivation and its relationship with language choice and learning effort. The modern language journal, 2005, vol. 89(1), pp. 19-36. https://doi.org/10.1111/j.0026-7902.2005.00263.x

[13] Su, C.H., Cheng, C.H. A mobile gamification learning system for improving the learning motivation and achievements. Journal of Computer Assisted Learning, 2015, vol. 31(3), pp. 268-286. https://doi.org/10.1111/jcal.12088

[14] Tuckman, B.W. The effect of learning and motivation strategies training on students' achievement. Journal of College Student Development, 2003, vol. 44(3), pp. 430-437. https://doi.org/10.1353/csd.2003.0034

[15] Alsowat, H. An EFL flipped classroom teaching model: Effects on English language higher-order thinking skills, student engagement and satisfaction. Journal of Education and Practice, 2016, vol. 7(9), pp. 108-121.

[16] Cheok, M.L., \& Wong, S.L. Predictors of e-learning satisfaction in teaching and learning for school teachers: A literature review. International Journal of Instruction, 2015, vol. 8(1), pp. 75-90.

[17] Bini, M., Masserini, L. Students' satisfaction and teaching efficiency of university offer. Social Indicators Research, 2016, vol. 129(2), pp. 847-862. https://doi.org/10.1007/ $\underline{\text { s11205-015-1141-0 }}$

[18] Lee, Y.J. A study on the effect of teaching innovation on learning effectiveness with learning satisfaction as a mediator. World Transactions on Engineering and Technology Education, 2011, vol. 9(2), pp. 92-101.

[19] Guolla, M. Assessing the teaching quality to student satisfaction relationship: Applied customer satisfaction research in the classroom. Journal of marketing theory and practice, 1999, vol. 7(3), pp. 87-97. https://doi.org/10.1080/10696679.1999.11501843

[20] Cleak, H., Smith, D. Student satisfaction with models of field placement supervision. Australian Social Work, 2012, vol. 65(2), pp. 243-258. https://doi.org/10.1080/0312407x. $\underline{2011.572981}$ 
[21] Joo, Y.J., Lim, K.Y., Kim, E.K. Online university students' satisfaction and persistence: Examining perceived level of presence, usefulness and ease of use as predictors in a structural model. Computers \& education, 2011, vol. 57(2), pp. 1654-1664. https://doi.org/ 10.1016/j.compedu.2011.02.008

[22] Calvo, R.A., Markauskaite, L., Trigwell, K. Factors affecting students' experiences and satisfaction about teaching quality in engineering. Australasian Journal of Engineering Education, 2010, vol. 16(2), pp. 139-148. https://doi.org/10.1080/22054952.2010.11464049

[23] Mohammed, G.S., Wakil, K., Nawroly, S.S. The effectiveness of microlearning to improve students' learning ability. International Journal of Educational Research Review, 2018, vol. 3(3), pp. 32-38. https://doi.org/10.24331/ijere.415824

[24] Seo, N.S., Woo, S.J., Ha, Y.J. The effects of self-directed learning ability and motivation on learning satisfaction of nursing students in convergence blended learning environment. Journal of digital Convergence, 2015, vol. 13(9), pp. 11-19. https://doi.org/10.14400/jdc. 2015.13.9.11

[25] Kim, Y.J., Yoo, H., Park, M. Effect of motive for major selection on major satisfaction, campus-life satisfaction, and self-directed learning ability among nursing students. Journal of the Korea Academia-industrial cooperation Society, 2016, vol. 17(10), pp. 261-270. https://doi.org/10.5762/kais.2016.17.10.261

[26] Choi, G.H., Kwon, S. The influence of self-directed learning ability and satisfaction with practicum on confidence in performance of fundamental nursing skills among nursing students. Journal of the Korea Academia-Industrial cooperation Society, 2017, vol. 18(5), pp. 626-635. https://doi.org/10.5762/kais.2016.17.8.172

[27] Hoskins, S.L., Van Hooff, J.C. Motivation and ability: which students use online learning and what influence does it have on their achievement?. British journal of educational technology, 2005, vol. 36(2), pp. 177-192. https://doi.org/10.1111/j.1467-8535.2005.00451.x

[28] Babini, M.H., Kulish, V.V., Namazi, H. Physiological state and learning ability of students in normal and virtual reality conditions: Complexity-based analysis. Journal of Medical Internet Research, 2020, vol. 22(6), pp. 17945. https://doi.org/10.2196/17945

[29] Cheng, G., Chau, J. Exploring the relationship between students' self-regulated learning ability and their ePortfolio achievement. The Internet and Higher Education, 2013, vol. 17, pp. 9-15. https://doi.org/10.1016/j.iheduc.2012.09.005

[30] Siriwongs, P. Developing students' learning ability by dint of self-directed learning. Procedia-Social and Behavioral Sciences, 2015, 197, pp. 2074-2079. https://doi.org/10. 1016/j.sbspro.2015.07.577

[31] Shinkareva, O.N., \& Benson, A.D. The relationship between adult students' instructional technology competency and self-directed learning ability in an online course. Human Resource Development International, 2007, vol. 10(4), pp. 417-435. https://doi.org/10.1080/ 13678860701723737

[32] Vaughan, W. Effects of cooperative learning on achievement and attitude among students of color. The Journal of Educational Research, 2002, vol. 95(6), pp. 359-364. https://doi. org/10.1080/00220670209596610

[33] Mahmoudi, E., Razak, N.Z.B.A. Attitude and students' performance in computer assisted English language learning for learning vocabulary. Procedia-Social and Behavioral Sciences, 2012, vol. 66, pp. 489-498. https://doi.org/10.1016/j.sbspro.2012.11.293

[34] Akinbobola, A.O. Enhancing students attitude towards Nigerian senior secondary school physics through the use of cooperative, competitive and individualistic learning strategies. Australian Journal of Teacher Education, 2009, vol. 34(1), pp. 1-9. https://doi.org/10. $\underline{14221 / \text { ajte.2009v34n1.1 }}$ 
Paper — Research on the Relationship between Students' Learning Adaptability and Learning...

[35] Bhaskar, C.V., \& Soundiraraj, S. A Study on Change in the Attitude of Students towards English Language Learning. English language teaching, 2013, vol. 6(5), pp. 111-116. https://doi.org/10.5539/elt.v6n5p111

[36] Nugraha, I., Putri, N.K., \& Sholihin, H. An Analysis of the Relationship between Students' Scientific Attitude and Students' Learning Style in Junior High School. Journal of Science Learning, 2020, vol. 3(3), pp. 185-195. https://doi.org/10.17509/jsl.v3i3.22873

[37] Farooq, M.U., Javid, C. Z. Attitude of students towards E-learning: A study of English language learners at Taif University English Language Centre. NUML Journal of Critical Inquiry, 2012, vol. 10(2), pp. 17-28.

[38] Ajewole, G.A. Effects of discovery and expository instructional methods on the attitude of students to biology. Journal of Research in Science teaching, 1991, vol. 28(5), pp. 401409. https://doi.org/10.1002/tea.3660280504

[39] Van der Kleij, F.M., Feskens, R.C., Eggen, T.J. Effects of feedback in a computer-based learning environment on students' learning outcomes: A meta-analysis. Review of educational research, 2015, vol. 85(4), pp. 475-511. https://doi.org/10.3102/0034654314564881

[40] Frenzel, A.C., Pekrun, R., Goetz, T. Perceived learning environment and students' emotional experiences: A multilevel analysis of mathematics classrooms. Learning and Instruction, 2007, vol. 17(5), pp. 478-493. https://doi.org/10.1016/j.learninstruc.2007.09.001

[41] Tarr, J.E., Reys, R.E., Reys, B.J., Chávez, Ó., Shih, J., \& Osterlind, S. J. The impact of middle-grades mathematics curricula and the classroom learning environment on student achievement. Journal for research in mathematics education, 2008, vol. 39(3), pp. 247-280.

[42] Harrati, N., Bouchrika, I., Tari, A., Ladjailia, A. Exploring user satisfaction for e-learning systems via usage-based metrics and system usability scale analysis. Computers in Human Behavior, 2016, vol. 61, pp. 463-471. https://doi.org/10.1016/j.chb.2016.03.051

[43] Violante, M.G., Vezzetti, E. Virtual interactive e - learning application: An evaluation of the student satisfaction. Computer Applications in Engineering Education, 2015, vol. 23(1), pp. 72-91. https://doi.org/10.1002/cae.21580

[44] Pham, L., Limbu, Y.B., Bui, T.K., Nguyen, H.T., Pham, H.T. Does e-learning service quality influence e-learning student satisfaction and loyalty? Evidence from Vietnam. International Journal of Educational Technology in Higher Education, 2019, vol. 16(1), pp. 1-26. https://doi.org/10.1186/s41239-019-0136-3

[45] Yilmaz, R. Exploring the role of e-learning readiness on student satisfaction and motivation in flipped classroom. Computers in Human Behavior, 2017, vol. 70, pp. 251-260. https://doi.org/10.1016/j.chb.2016.12.085

[46] Wong, L.W., Tan, G. W.H., Hew, J.J., Ooi, K.B., Leong, L. Y. Mobile social media marketing: a new marketing channel among digital natives in higher education?. Journal of Marketing for Higher Education, 2010, pp. 1-25. https://doi.org/10.1080/08841241.2020. $\underline{1834486}$

[47] Lewis, S., Pea, R., \& Rosen, J. Beyond participation to co-creation of meaning: mobile social media in generative learning communities. Social Science Information, 2010, vol. 49(3), pp. 351-369. https://doi.org/10.1177/0539018410370726

[48] Gikas, J., Grant, M.M. Mobile computing devices in higher education: Student perspectives on learning with cellphones, smartphones \& social media. The Internet and Higher Education, 2013, vol. 19, pp. 18-26. https://doi.org/10.1016/j.iheduc.2013.06.002 
Paper — Research on the Relationship between Students' Learning Adaptability and Learning...

\section{$7 \quad$ Author}

Guanghui Liu is a Lecturer in School of Economics and Management, Jiaozuo University, Jiaozuo, Henan, 454000, China.

Article submitted 2021-10-17. Resubmitted 2021-12-05. Final acceptance 2021-12-10. Final version published as submitted by the author. 